\title{
Four new records of stranded Kemp's ridley turtle Lepidochelys kempii in the NW Iberian Peninsula
}

\author{
Pablo Covelo ${ }^{1,3^{*}}$, Lidia Nicolau ${ }^{2,3}$ and Alfredo López ${ }^{1,3}$
}

\begin{abstract}
Background: The critically endangered Kemp's ridley turtle (Lepidochelys kempii) has a reduced distribution range concentrated in the Gulf of Mexico and only a few pelagic stage juveniles occasionally strand on European coasts. In the study area only three individuals have been recorded previously, most recently in 2001.

Results: Four new records of Kemp's ridley turtle are reported from the northwestern Iberian Peninsula in 2014. All of them were juvenile with a maximum straight carapace length of $26.8 \mathrm{~cm}$. Two of them were found alive, but died on the first two days at the rehabilitation centres. The largest individual stranded in November presented signs of incidental capture in fishing gears.

Conclusions: The four records in just one year are a significant increase compared to previous data for the species in this area, and the data obtained contribute to the local knowledge on species phenology, size, distribution and threats.

Keywords: Kemp's ridley turtle, Lepidochelys kempii, Iberian Peninsula, Distribution, Sea turtle, Strandings

Abbreviations: CCL, Curved carapace length; CCW, Curved carapace width; CEMMA, Coordinadora para o Estudo dos Mamíferos Mariños; IUCN, Internation Union for Conservation of Nature; SCL, Straight carapace length;

SCW, Straight carapace width; SPVS, Sociedade Portuguesa de Vida Selvagem; TL, Total length
\end{abstract}

\section{Background}

In spite of a recent increase in population (Márquez et al. 2005) the Kemp's ridley turtle Lepidochelys kempii (Garman 1880) is considered the most threatened sea turtle species in the world, being categorized as critically endangered by the International Union for Conservation of Nature (IUCN) (Marine Turtle Specialist Group 1996). The Kemp's ridley turtle has a small, restricted geographic range compared to other sea turtles species (Zug et al. 1997). The nesting areas of this species are mainly located in the Mexican coast of the Gulf of Mexico (Márquez, 1990; Bowen et al. 1994) with some secondary isolated rookeries in Texas, Florida, South

\footnotetext{
* Correspondence: cemmaorganizacion@gmail.com

${ }^{1}$ Coordinadora para o Estudo dos Mamíferos Mariños (CEMMA), P.O. Box 15. 36380, Pontevedra, Gondomar, Spain

${ }^{3}$ Departamento de Biologia \& CESAM, Campus de Santiago, Universidade de Aveiro, 3810-193 Aveiro, Portugal

Full list of author information is available at the end of the article
}

Carolina and North Carolina (Meylan et al. 1990; Bowen et al. 1994; Johnson et al. 1999).

Adult and immature Kemp's ridley occur year-round in the Gulf of México, and juveniles are found at sea in the northwestern Atlantic Ocean as far as Nova Scotia and Canada (National Marine Fisheries Services US, Service FaW and SEMARNAT 2011). Occasionally some small turtles are also known to drift into European waters during the winter months (Brongersma 1972; Márquez 1994; Witt et al. 2007). There are several documented records showing the presence of Kemp's ridley turtle in the waters around Azores (Brongersma 1972; Bolton and Martins 1990), Madeira (Brongersma 1972), British Islands and France (Brongersma 1972; Witt et al. 2007; Penrose and Gander, 2015) and in the Mediterranean Sea (Brongersma and Carr 1983; Tomás et al. 2003; Oliver and Pigno 2005; Tomás and Raga 2008; Insacco and Spadola 2010; Carreras et al. 2014). 
In the NW Iberian Peninsula, previous documented records included only two individuals in the coast of Galicia (Spain), the most recently in 1998 (Fernández 1988; Faraldo and Galán 1999), and one individual in Portugal in 2001 (Dellinger 2008).

The present study provides a new report on the presence of and an increase in the records of Kemp's ridley turtles in the waters around the NW Iberian Peninsula within a short time of ten months. Our work also contributes to the knowledge of the distribution of this species in the north-eastern Atlantic and provide insights to the main threats in the area to contribute to conservation efforts of this species in international waters.

\section{Methods}

\section{Study area}

The NW Iberian Peninsula coast is about 1,500 km long ranging from Ría de Ribadeo $\left(43^{\circ} 33.20^{\prime} \mathrm{N} ; 07^{\circ} 02.00^{\prime} \mathrm{W}\right.$ Spain) to Peniche $\left(39^{\circ} 21.00^{\prime} \mathrm{N}\right.$; 09 $22.00^{\prime} \mathrm{W}$ Portugal) (Fig. 1). The Galician coastline (about 1,200 km in length between Ría de Ribadeo and River Miño estuary) is characterized by a series of large, coastal inlets (rías). The NW Portuguese coast (about $300 \mathrm{~km}$ in length between River Minho and Peniche) presents a wider and flat continental shelf $(40-70 \mathrm{Km})$ (Fiúza 1983). This whole area has the influence of winds from south and south-west in autumn and winter, and northerly winds in spring and summer.

\section{Data collection and analysis}

In the study area, two stranding networks are established: Coordinadora para o Estudo dos Mamíferos Mariños (CEMMA) in Galicia (NW of Spain) and Sociedade Portuguesa de Vida Selvagem (SPVS) in Portugal, since 1990 and 2000, respectively. These strandings networks record turtles and marine mammals stranded on the beaches, collect samples for Galician and Portuguese Marine Animal Tissue Banks and recover injured individuals for rehabilitation. They are coordinated via a $24 \mathrm{~h}$ telephone hotline.

Turtles were moved by the strandings networks mobile units to rehabilitation installations of CEMMA and SPVS to proceed with the veterinary examination and rehabilitation of the two individuals found alive and to carry out the necropsy of the dead ones following detailed protocols (Sociedad Española de Cetáceos 1999; Wyneken 2001). Turtles were measured (total length [TL]; straight carapace length [SCL]; curved carapace length [CCL]; straight carapace width $[\mathrm{SCW}]$ and curved carapace width [CCW] according to Bolten 1999), weighed, identified to species level, and the likely cause of death determined based on a complete external and internal examination. In cases when there was evidence

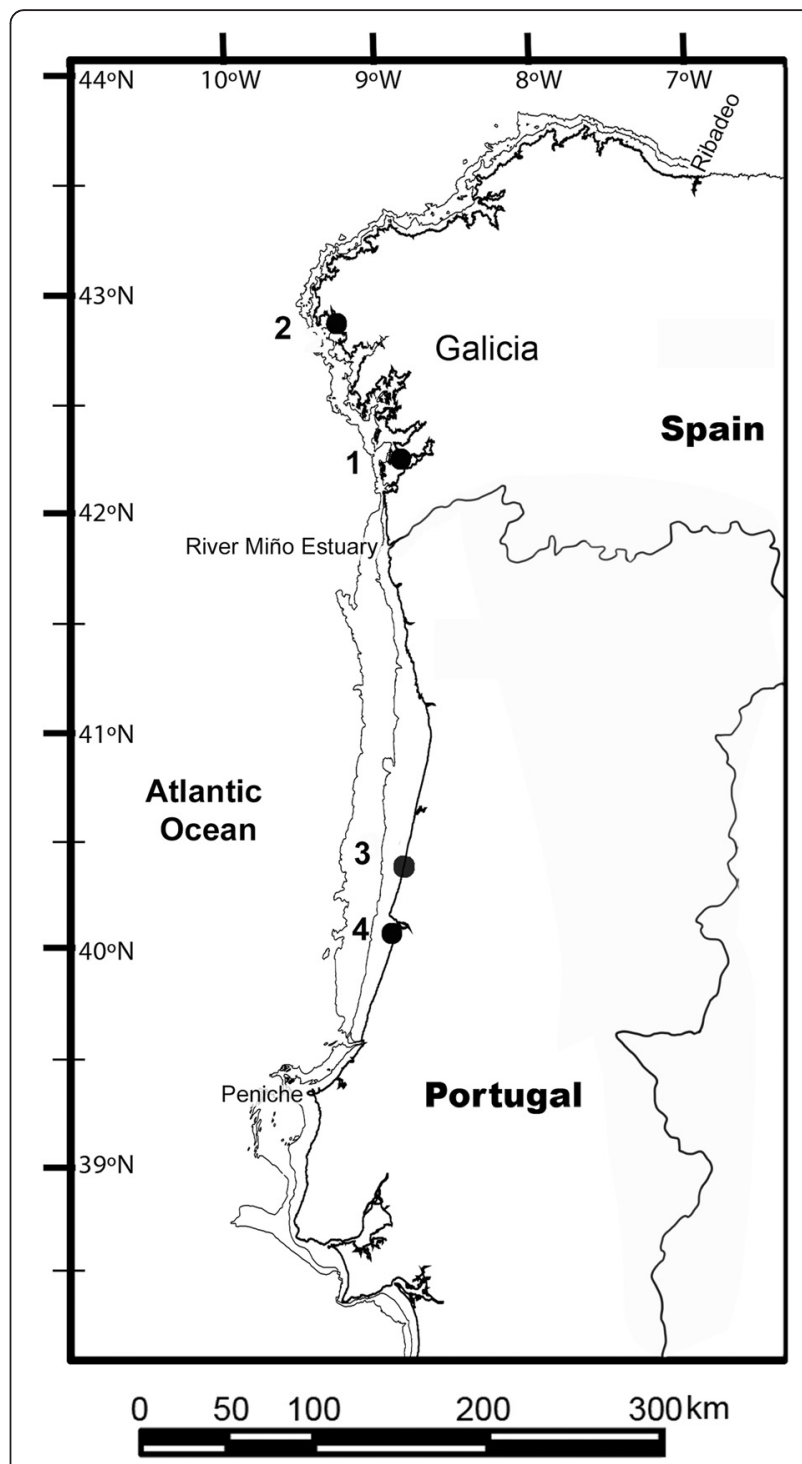

Fig. 1 Location of four new records of stranded Kemp's ridley turtle in the NW Iberian Peninsula between February and November, 2014. Turtles are numbered in chronological order (Table 1)

of multiple lesions, the most severe and recent was assigned as the primary cause of stranding.

The approximated age of the turtles was estimated using the carapace length and applying reference growth models (Chaloupka and Zug, 1997; Zug et al. 1997).

\section{Results}

In 2014 four new individuals of Kemp's ridley turtle were recorded stranded on the NW Iberian Peninsula coast (two in Spain and two in Portugal) (Fig. 1). The four turtles were identified as Lepidochelys kempii based on their diagnostic features: the presence of a small pore near the rear margin of each of the inframarginal scutes, the coloration of the skin (white bright green), the circular shape of the carapace, the presence of five pairs 
of coastal scutes, and triangular head with two pairs of frontal scales (Márquez, 1990). The four specimens had SCL of between 19.5 and $26.8 \mathrm{~cm}$ (Table 1), and therefore they were considered juveniles in their oceanic life stage (Collard and Ogren, 1990; Witherington et al. 2012). The first three individuals stranded between 11th February and 5th March, within 22 days, and the fourth one stranded on 11th November. Two of the turtles reported in the present study were found alive and were transferred to rehabilitation centres in less than two hours, but died after one and two days (Table 1).

The first individual, found alive in Cangas do Morrazo, Spain, presented small carapace and plastron abrasions, no food in digestive tract and emaciation was noticeable in the neck (Fig. 2), indicating malnourishment. The second individual, found dead on Carnota, Spain, had head, carapace and plastron abrasions, consistent with stranding, and goose barnacles (Lepas anatifera) on the plastron. The third individual, found alive in Cantanhede, Portugal, had head and carapace abrasions, probably due to stranding, an ulcerative lesion in the carapace and epibiont crustaceans (goose barnacles, Lepas anatifera). Internal observations of its organs indicated sepsis. The fourth individual, found dead in Figueira da Foz, Portugal, had lacerations on its anterior flippers, consistent with incidental capture in nets, hematomas in posterior flippers and evidence of feeding (crustaceans, unidentified crabs) in upper digestive tract.

\section{Discussion}

The four turtles were juveniles with a SCL of between 19.5 and $26.8 \mathrm{~cm}$, so according to published growth models derived from skeletonchronological studies in relation with the carapace length (Chaloupka and Zug, 1997; Zug et al. 1997), they had an estimated age of 2 years for the first three individuals and nearly 3 years for the fourth turtle. The time of year in which they stranded is consistent with previous records of the species found stranded on the European continental coasts, that

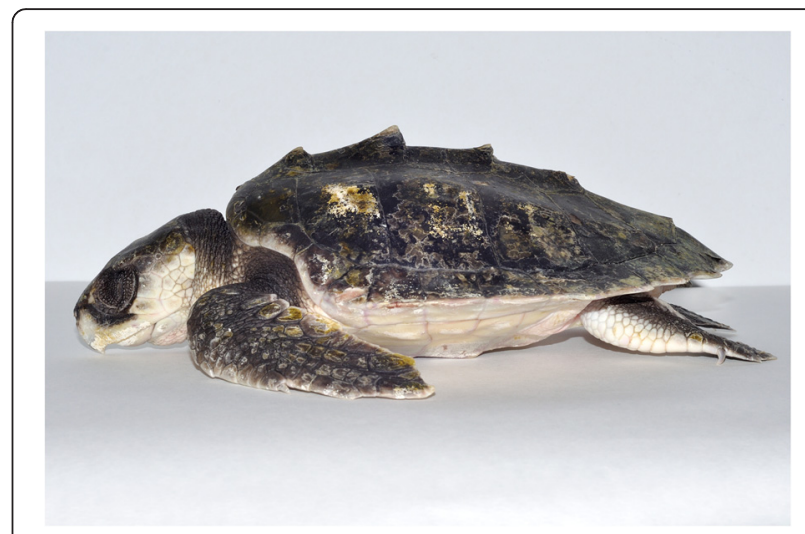

Fig. 2 Kemp's ridley turtle stranded in Cangas do Morrazo, Spain, 11/02/2014. Emaciation was noticeable in the neck

are more usually found during the autumn and winter (Brongersma 1972; Witt et al. 2007). Goose barnacles found on the first and third turtles are commonly attached to floating objects and when they are found on dead or weak turtles that indicates that they spent a long period floating at the water's surface (De Loreto and Bondioli, 2008), and that is likely associated with a chronic condition such as poor nutrition, chronic infections, parasitic diseases, immune deficiency or a combination of some or all of these causes (Deem et al. 2009).

In the NW Iberian Peninsula, and especially during winter, the seawater temperature is low, sometimes below $10{ }^{\circ} \mathrm{C}$. The average sea surface temperature during the first three stranding events (February and first week in March) was around $12{ }^{\circ} \mathrm{C}$ (Feldman and McClain 2014). This low temperature could have been sufficient to affect the sea turtles physiology leading to coldstunning events, in which turtles become lethargic and float at the water's surface and, as a result, they may be unable to swim or feed (Schwartz 1978). Therefore, lack of feeding due to the low seawater temperature could explain the large weight differences up to $38 \%(0.99 \mathrm{~kg}$ and $1.37 \mathrm{~kg}$ ) between the two individuals that had

Table 1 Biometry and geographic data of the four new records of stranded Kemp's ridley turtle in the Iberian Peninsula

\begin{tabular}{lllll}
\hline & 1 & 2 & 3 & 4 \\
\hline Date & $11 / 02 / 2014$ & $21 / 02 / 2014$ & $05 / 03 / 2014$ & $11 / 11 / 2014$ \\
Location & Viñó Beach, Cangas do & Boca do Río, & Tocha Beach, Cantanhede, & Gala Beach, Figueira da Foz, \\
& Morrazo, Spain & Carnota, Spain & Portugal & Portugal \\
Status & Alive (died on first day) & Dead & Alive (died on second day) & Dead \\
TL $(\mathrm{cm})$ & 25.4 & 30.0 & 29.5 & 38.0 \\
SCL $(\mathrm{cm})$ & 19.5 & 21.4 & 21.4 & 26.8 \\
CCL (cm) & 21.0 & 23.5 & 23.9 & 29.0 \\
SCW $(\mathrm{cm})$ & 18.5 & 20.2 & 19.3 & 27.7 \\
CCW (cm) & 20.8 & 24.4 & 22.6 & 29.6 \\
Weight $(\mathrm{kg})$ & 0.99 & 1.62 & 1.37 & 2.65
\end{tabular}

$T L$ total length, $S C L$ straight carapace length, $C C L$ curved carapace length, $S C W$ straight carapace width, $C C W$ curved carapace width 
similar lengths to those found alive in February and March (Table 1). In the case of the turtle stranded in November in Portugal, sea temperature was around $18{ }^{\circ} \mathrm{C}$ and therefore cold stunning event is unlikely to explain this turtle stranding. Considering the necropsy findings, this individual was probably a victim of incidental capture by fisheries. Interactions with coastal fisheries, especially interactions with gill or trammel net fisheries, represents an important anthropogenic threat to other sea turtle species (loggerhead Caretta caretta and leatherback Dermochelys coriacea) in the Portuguese continental coast (Nicolau et al. 2014).

\section{Conclusions}

Four new records in one year are a significant increase compared to previous data for the species in this area. In UK and Republic of Ireland an increase in the stranded Kemp's ridley turtle has also been reported in 2014 with 7 stranded turtles, while in the previous ten year period 2004-2013 the average rate was just 1 stranded individual (Penrose and Gander, 2015). It will be important to pay attention to the occurrence of the species in the next years in the European coasts to find out whether the 2014 numbers are isolated findings or whether they indicate a trend.

\section{Acknowledgements}

We thank the staff of Dirección Xeral de Conservación da Natureza that found the two animals at the Galician beaches and took care of the alive one in the first hours. We also thank Juan Ignacio Díaz for helping with the field work and Ángela Llavona and Marisa Ferreira for their comments and suggestions during the writing of this note. The Quiaios Marine Animal Rehabilitation Centre provided technical support for the turtle found in Portugal. We are very grateful to the anonymous reviewers for their very useful comments that improved this note.

\section{Funding}

PC is supported by a research grant BI/UI88/7056/2014, AL is supported by a postdoctoral grant SFRH/BPD/82407/2011 and LN is supported by PhD grant SFRH/BD/51416/2011 both from the Portuguese Foundation for Science and Technology of the Portuquese Ministry of Science and Education. The Galician stranding network is supported by the regional government Xunta de Galicia, cofinanced with European Regional Development Funds (ERDF/FEDER).

\section{Authors' contributions}

$P C, L N$ and $A L$ wrote the manuscript. PC and LN participated in the field data collection and $\mathrm{AL}$ prepared the figures. All authors approved the final manuscript.

\section{Competing interests}

The authors declare that they have no competing interests.

\section{Ethics approval and consent to participate}

For the stranded animal management and the collection of biological samples all the legal permits were provided by the environmental administrations of Portugal and Galicia (Spain).

\section{Author details}

${ }^{1}$ Coordinadora para o Estudo dos Mamíferos Mariños (CEMMA), P.O. Box 15 36380, Pontevedra, Gondomar, Spain. ${ }^{2}$ Sociedade Portuguesa de Vida Selvagem (SPVS). Departamento de Biologia, Campus de Gualtar, Universidade do Minho, 4710-057 Braga, Portugal. ${ }^{3}$ Departamento de Biologia \& CESAM, Campus de Santiago, Universidade de Aveiro, 3810-193 Aveiro, Portugal.
Received: 2 August 2016 Accepted: 3 August 2016

Published online: 31 August 2016

\section{References}

Bolten $A B$. Techniques for measuring sea turtles. In: Eckert $K L$, Bjorndal KA, Abreu-Grobois FA, Donnelly $M$, editors. Research and management techniques for the conservation of sea turtles. Washington: IUCN/SSC Marine Turtle Specialist Group; 1999. p. 110-4.

Bolton AB, Martins HR. Kemp's ridley captured in the Azores. Mar Turt Newsl. 1990;48:23.

Bowen BW, Conant TA, Hopkins-Murphy SR. Where are they now? The Kemp's Ridley Headstart Project. Conserv Biol. 1994;8(3):853-6.

Brongersma LD. European Atlantic turtles. Zoologsische Verhandelingen. 1972;121. $318 \mathrm{pp}$

Brongersma, L.D. and Carr, A.F. (1983).Lepidochelys kempii (Garman) from Malta. Proceedings of the Koninklijke Nederlandse Akademie van Wetenschappen, Series C 86, 445-454

Carreras C, Monzón-Argüello C, López-Jurado LF, Calabuig P, Bellido JJ, Castillo JJ, Sánchez P, Medina P, Tomás J, Gozalbes P, Fernández G, Marco A, Cardona L. Origin and dispersal routes of foreign green and Kemp's ridley turtles in Spanish Atlantic and Mediterranean waters. Amphibia-Reptilia. 2014;35:73-86.

Chaloupka M, Zug GR. A polyphasic growth function for the endangered Kemp's ridley sea turtle, Lepidochelys kempii. Fish Bull. 1997;95(4):849-56.

Collard SB, Ogren LH. Dispersal scenarios for pelagic post-hatchlings sea turtles. Bull Mar Sci. 1990;47:233-43.

De Loreto BO, Bondioli ACV. Epibionts associated with green sea turtles (Chelonia mydas) from Cananéia, Southeast Brazil. Mar Turt Newsl. 2008; 12:5-8.

Deem SL, Norton TM, Mitchell M, Segars A, Alleman AR, Cray C, Poppenga RH, Dodd M, Karesh WB. Comparison of blood values in foraging, nesting, and stranded loggerhead turtles (Caretta caretta) along the coast of Georgia, USA. J Wildl Dis. 2009;45(1):41-56.

Dellinger, T. (2008). Tartarugas marinhas. In: Loureiro, A. Ferrand de Almeida,N. Carretero, M.A. e Paulo, O.S. (eds.) Atlas dos Anfibios e Repteis de Portugal. Lisboa: Instituto da Conservação da Natureza e da Biodiversidade; $257 \mathrm{pp}$

Faraldo, R. and Galán, P. (1999). Lepidochelys kempii (Tortuga golfina) en la costa de A Coruña. Boletín de la Asociación Herpetológica Española, 10:17

Feldman, G. C. and McClain, C.R. (2014), http://oceancolor.gsfc.nasa.gov, Ocean Color Web, Eds. Kuring, N., Bailey, S. W., Franz, B. A., Meister, G., Werdell, P. J., Eplee, R. E.. 05-09-2014. NASA Goddard Space Flight Center. 11-12-2014. http://oceancolor.gsfc.nasa.gov

Fernández E. Islas Cíes, Serie Naturaleza Gallega. Vigo: Asociación Gallega para la Cultura y la Ecología; 1988. 232pp.

Fiúza, A.F., 1983. Upwelling patterns off Portugal. In: Suess, E., Thiede, J. (Eds.), Coastal Upwelling. New York: Plenum Publishers; pp. 85-87

Garman, S. On certain species of Chelonidae. Bulletin of the Museum of Comparative Zoology, Harvard University. 1880;6:123-126.

Insacco G, Spadola F. First record of Kemp's ridley sea turtle, Lepidochelys kempii (Garman 1880) (Cheloniidae), from the italian waters (Mediterranean Sea). Acta Herpetologica. 2010;5(1):113-7.

Johnson SA, Bass AL, Libert B, Marshall M, Fulk D. Kemp's ridley (Lepidochelys kempii) nesting in Florida. Florida Scientist. 1999;62:3-4.

Marine Turtle Specialist Group (1996). Lepidochelys kempii. In: IUCN 2014. IUCN Red List of Threatened Species. Version 2014.3. <www.iucnredlist.org>. Downloaded on December 30th, 2014

Márquez, M.R. (1990). FAO species catalogue Vol.11 Sea turtles of the world. An annotated and illustrated catalogue of sea turtle species known to date. FAO Fisheries Synopsis No. 125. Vol. 11. Rome. FAO. 81 pp.

Márquez, M.R. (1994). Synopsis of the biological data on the Kemp's Ridley turtle Lepidochelys kempii (Garman 1880). NOAA Technical Memorandum. NMFS-SEFCSC-343.

Márquez MR, Burchfield PM, Diaz J, Sanchez M, Carrasco M, Jimenez C, Leo A Bravo R, Pena J. Status of Kemp's Ridley sea turtle, Lepidochelys kempii. Chelonian Conserv Biol. 2005:4:761-6.

Meylan A, Castaneda P, Coogan C, Lozon T, Fletemeyer J. First recording nesting by Kemp's ridley in Florida, USA. Mar Turt Newsl. 1990:48:8-9.

National Marine Fisheries Services US, Service FaW and SEMARNAT. Bi-National Recovery Plan for the Kemp's Ridley sea turtle (Lepidochelys kempii). Silver Spring, Mariland: National Marine Fisheries Service; 2011. 
Nicolau, L., Marçalo, A., Ferreira, M., Sequeira, M., Vingada, J., Eira, C. (2014). Sea turtle strandings along the Portuguese continental coast: distribution, patterns and insights of bycatch. In: Proceedings of XIII Iberian Congress of Herpetology, University of Aveiro, Aveiro, 30th September - 04th October 2014, pp. 160-161.

Oliver G, Pigno A. Première observation d'une Tortue de Kemp, Lepidochelys kempii (Garman, 1880), (Reptilia, Chelonii, Cheloniidae) sur les côtes françaises de Méditerranée. Bulletin de la Société Herpétologique de France. 2005;116:31-8.

Penrose, R.S. and Gander, L.R. (2015). British Isles \& Republic of Ireland marine turtle strandings and sightings annual report 2014. Marine Environmental Monitoring http://www.strandings.com/Graphics\%20active/2014\%20 Turtle\%20Annual\%20Strandings\%20Report.pdf

Schwartz, F.J. (1978). Behavioural and tolerance responses to cold water temperature by three species of sea turtles (Reptilia, Cheloniidae) in North Carolina. Florida Marine Research Publications 33, 16-18

Sociedad Española de Cetáceos. Recopilación, análisis, valoración y elaboración de protocolos sobre las labores de observación, asistencia a varamientos y recuperación de mamíferos y tortugas marinas de las aguas españolas, Dirección General de Conservación de la Naturaleza. Madrid: Ministerio de Medio Ambiente; 1999. p. 268.

Tomás, J. and Raga, J.A. (2008). Occurrence of Kemp's ridley sea turtle (Lepidochelys kempii) in the Mediterranean. Marine Biodiversity Records Vol1, e58, 1-2

Tomás J, Formia A, Fernández M, Raga JA. Occurrence and genetic analyses of a Kemp's ridley sea turtle (Lepidochelys kempii) in the Mediterranean Sea. Sci Mar. 2003;67:367-9.

Witherington B, Hirama S, Hardy R. Young sea turtles of the pelagic Sargassum-dominated drift community: habitat use, population density and threats. Mar Ecol Prog Ser. 2012;463:1-22.

Witt MJ, Penrose R, Godley BJ. Spatio-temporal patterns of juvenile marine turtle occurrence in waters of the European continental shelf. Mar Biol. 2007;151:873-85

Wyneken, J. (2001). The Anatomy of Sea Turtles. U.S. Department of Commerce NOAA Technical Memorandum NMFS-SEFSC-470, 172 pp.

Zug GR, Kalb HJ, Luzard SJ. Age and growth in wild Kemp's ridley seaturtles Lepidochelys kempii from skeletonchronological data. Biol Conserv. 1997;80:261-8.

\section{Submit your next manuscript to BioMed Central and we will help you at every step:}

- We accept pre-submission inquiries

- Our selector tool helps you to find the most relevant journal

- We provide round the clock customer support

- Convenient online submission

- Thorough peer review

- Inclusion in PubMed and all major indexing services

- Maximum visibility for your research

Submit your manuscript at www.biomedcentral.com/submit 